\title{
Hypoglycemic, Hepatoprotective and Nephroprotective Effects of Methanolic Leaf Extract of Heinsia crinita (Rubiaceae) in Alloxan-induced Diabetic Albino Wistar Rats
}

\author{
1, Ebong, P.E., ${ }^{2,}$ Igile, G.O., ${ }^{3,}$ Mgbeje, B.I.A., ${ }^{4,}$ Iwara, I.A., ${ }^{5,}$ Odongo, A.E; \\ 6, Onofiok, U.L., ${ }^{7}$ Oso, E.A., \\ Department of Biochemistry, Faculty of Basic Medical Sciences, \\ University of Calabar, P.M.B 1115, Calabar, Nigeria.
}

\begin{abstract}
Type 1 diabetes is associated with damage to the liver, kidney and pancreas of patients. The damage varies in proportion and susceptibility among diabetic patients of type 1 class. This study assessed the hypoglycemic, hepatoprotective and nephroprotective activities of whole methanolic leaf extract of Heinsia crinita (HC) in alloxan-induced diabetic albino Wistar rats. Twenty four (24) rats weighing 140-180g were divided into 4 groups of 6 rats each. Group 1 served as normal control (NC), while Group 2 served as diabetic control (DC) and both received placebo treatment consisting of $0.2 \mathrm{ml}$ of 50\% DMSO respectively. Group 3 was treated with standard insulin (5iu/kg b.w) and Group 4 was treated with $400 \mathrm{mg} / \mathrm{kg}$ b.w of the methanol extract of Heinsia crinita $(H C)$ twice daily via oral gastric intubation. After 14 days, the animals were sacrificed and serum was analyzed for glucose, oxidative stress biomarkers and electrolyte profile. The results showed that $H C$ reduced serum glucose level by 15\% within 14 days, while the DC showed no reduction. The results further showed significant $(p<0.05)$ decrease in ALT, AST and ALP activity in groups 4 and 3, when compared with group 2 (DC) which gave high values of these enzymes. Group 4 showed high values of $\mathrm{K}^{+}(10.93 \pm 0.10 \mathrm{Mmol} / \mathrm{l})$ and $\mathrm{Cl}^{-}(353.23 \pm 0.34 \mathrm{Mmol} / \mathrm{l})$ but lower $\mathrm{Na}^{+}(71.06 \pm 12.94 \mathrm{Mmol} / \mathrm{l})$ and urea $(66.04 \pm 6.06 \mathrm{Mmol} / \mathrm{l})$ values when compared to DC with low values of $\mathrm{K}^{+}(3.83 \pm 0.82 \mathrm{Mmol} / \mathrm{l})$ and $\mathrm{Cl}^{-}(127.09 \pm 14.43 \mathrm{Mmol} / \mathrm{l})$ but high values of $\mathrm{Na}^{+}(203.00 \pm 14.47 \mathrm{Mmol} / \mathrm{l})$ and urea $(86.00 \pm 14.13 \mathrm{Mmol} / \mathrm{l})$ respectively. Electrolyte modulation by the plant extract was shown in this study to be better than insulin. These findings showed that Heinsia crinita may possess antidiabetic properties and beneficial in the management of Type 1 diabetes and its attendant liver and kidney complications.
\end{abstract}

Key word. Hencia crinita, Alloxan, Type 1 Diabetes, Hepatoprotective, Nephroprotective

\section{INTRODUCTION}

There are two types of diabetes afflicting mankind. Type 1 diabetes causes damage to the liver, kidney and pancreatic $\beta$-cells of patients. This damage varies in proportion and susceptibility from one individual patient to another. The liver is a vital organ in humans, which has a wide range of functions including detoxification of foreign substances in the body as well as serving as the power house for protein synthesis. Other functions of the liver includes, building complex molecules from simple substances absorbed from the digestive tract, neutralization of toxins, manufacture of bile which aids fat digestion and removal of toxins through the bowels (Maton et. al 1993).

On the other hand, the kidneys are vital organs that function to keep the blood clean and maintain chemical balance within. They process blood to extract waste products and extra water. These by products become urine to be ultimately excreted from the body. The kidney serves many other important functions, including, filtering out wastes to be excreted in the urine, regulating blood pressure via both urinary excretion of wastes and initiating the renin-angiotensen hormone regulatory system, regulating an acid-base balance via the bicarbonate system and stimulating red blood cell production via the release of the hormone erythropoietin.

The pancreas contains cells that produce juices to break down fats and proteins and a hormone known as insulin to balance blood sugar content in the human body.

Any abnormality to these organs may lead to organ dysfunction and threat to human life. Type 1 diabetes is one of such causes of damage to these organs leading to organ dysfunction and endocrine related diseases which may be life threatening. 
Several therapies are available for the treatment of type 1 diabetes-induced hepatotoxicity, oxidative stress and nephrotoxicity. These therapies include insulin and various oral antidiabetic agents such as sulfonylurea, biguanides, and $\alpha$-glucosidase inhibitors, which are used as monotherapies or in combination to achieve better blood sugar regulation. Many of these oral antidiabetic agents have a number of serious adverse effects; thus, managing diabetes without any side effects is still a challenge (Wild et al 2004).

Several investigations have shown that herbs and plant materials rich in secondary compounds such as saponins, flavonoids, phenolic and polyphenolic compounds, arginine and glutamic acid possess hypoglycemic, hepatoprotective and nephroprotective effects in animal models (Gupta et. al. 2013; Efiong et. al. 2013; EnyiIdoh et al 2013).

In the absence of reliable liver and kidney-protective drugs in medical practice, herbs have become reliable substitutes and have so far played significant role in the ethnopharmacological management of various liver disorders and the accompanying oxidative stress (Efiong et. al. 2013). In this study, Heinsia crinita, was evaluated for its use in the management of type 1 diabetes in order to verify and establish the claims by ethnopharmacological practice.

Plants have long been known for their uses as food and medicine to humans. In some African cultures, vegetables like Heinsia crinita (Atama in Efik), Vernonia amygdalina (Bitter leaf), Ocimum gratissimum (Ntong in Efik), Gongronema latifolium (Utazi in Igbo) among others, are used in the treatment of many diseases including Types 1 and 2 diabetic conditions.

Heinsia crinita (Rubiaceae) also known as bush apple, is called "Atama", "Tonoposho" and Fumbwa in Efik, Yoruba and Igala cultures in Nigeria respectively. It is a scrambling shrub in secondary jungle or small tree of between $8-13 \mathrm{~m}$ in height, or as understory of high evergreen forest (Ajibesin, 2008). The plant is known across the tropical region from Guinea to western Cameroon and Equatorial Guinea, and across the Congo basin to East and South Central Africa. It's scrambling shrub is persistent and has very conspicuous leafy calyx-lobes, which produces sweet edible yellow or reddish fruits, which may be pleasantly acidic (Ajibesin, 2008) The plant has for several years been used by traditional herbal practitioners for the treatment of various ailments like sore throat, cough, catarrh and hypertension among other cases, and this is why it is classified as a medicinal plant (Abo, 2000; Mahesh, 2008).

Heinsia crinita is also used as a component of various herbal portions in ethnomedicine in the southwest of Nigeria against acute bacterial infections and for the treatment of infertility (Enyi-Idoh,et al, 2013). Phytochemical investigations have shown this plant to contain some bioactive constituents with beneficial medicinal properties. Some of these constituents include flavonoids, saponins, alkaloids, polyphenols, carotenoids, terpenoids and Vitamins A and C. Similar results have been reported for other medicinal herbs such as Vernonia amygdalina and Vernonia calvanoa (Igile et. al. 1994, 1995, \& 2013; Atangwho et al. 2009 \& 2010) and have been shown to contribute significantly in the management of hyperglycemia, diabetes and some of its complications.

It is on this premise that this work was designed to evaluate the hypoglycemic, hepatoprotective and nephroprotective effects of the methanolic leaf extract of Heinsia crinita in alloxan-induced Type 1 diabetes using Albino Wistar rats as study model, to confirm claims by ethno-pharmacology.

\section{Materials and Methods. \\ Collection and extraction of plants.}

Fresh, matured green leaves of Heinsia crinita were harvested from a local farm in the University of Calabar, Nigeria. The leaves were identified to be Heinsia crinita an d authenticated by Dr. Michael Eko, a botanist in the Department of Botany, University of Calabar, Nigeria. A voucher specimen (EUDB S01/13) was deposited in the Herbarium unit of the Department of Biochemistry, University of Calabar, Nigeria. The leaves were washed and air-dried in the laboratory at $20-25^{\circ} \mathrm{C}$. The dried leaves were manually grinded into powder form and the experimental sample of $500 \mathrm{~g}$ was weighed into a sterile plastic bag and stored under refrigeration $\left(4^{0} \mathrm{C}\right)$.

\section{Extraction preparation using different solvents}

Five hundred grams $(500 \mathrm{~g})$ of Heinsia crinita samples was soaked in 1.2 liters of a mixture of methanol and dichloromethane (1:1), and boiled under reflux for 30 minutes and left over night to cool. The extract was filtered with a chess material, followed by filtration with Whatman No. 1 filter paper to obtain a clear filtrate. The filtrate was concentrated in vacuo at low temperature $\left(30-35^{\circ} \mathrm{C}\right)$ to about one tenth the original volume using a rotary evaporator. The concentrate was allowed to stand in a water bath $\left(40^{\circ} \mathrm{C}\right)$ to completely dry off the alcohol to obtain $182 \mathrm{~g}$ methanolic extract. This was stored under refrigeration at $\left(4^{0} \mathrm{C}\right)$ until required. 


\section{Conditioning of experimental animals}

Twenty four (24) male albino Wistar rats weighing between 140-180g were obtained from the animal house of the Department of Biochemistry, University of Calabar, Nigeria. The animals were allowed to acclimatize for three (3) weeks in the animal house of the Department of Biochemistry. They were housed in well ventilated cages and kept under controlled environmental conditions of temperature $\left(25 \pm 5^{\circ} \mathrm{C}\right)$, relative humidity $(50 \pm 5 \%)$ and 12 hour light/dark cycle.

\section{Induction of Diabetes}

Hyperglycemia was induced by a single i.p. injection of $150 \mathrm{mg} / \mathrm{kg}$ of alloxan monohydrate (SigmaAldrich, Inc, St. Louis, MO 63103, U.S.A.) in sterile saline solution. Hyperglycemia was confirmed after 5 days of alloxan injection, and hyperglycemic rats (glucose level $>150 \mathrm{mg} / \mathrm{dl}$ ) were separated and divided into three (3) groups of 6 rats each for anti-diabetic studies.

\section{Experimental Design}

The twenty four (24) albino rats were divided into four (4) groups of six (6) rats each. Group 1 served as normal control (NC) and was not induced with diabetes. Group 1 animals received $0.2 \mathrm{ml}$ placebo of $50 \%$ DMSO. Group 2 served as the diabetic control (DC) and was not treated. Group 3 was diabetic and treated with standard insulin drug at a dose of $5 \mathrm{IU} / \mathrm{kg}$ b.w. Group 4 was also diabetic and was treated orally with $400 \mathrm{mg} / \mathrm{kg}$ bw of methanolic plant extract (HC) via gastric intubation twice daily (6 hour interval between treatments) .

The plant extract was reconstituted in 50\% dimethyl sulphoxide (DMSO) before use. The HC extract drug dose used was based on the pre-determined LD $_{50}$ (Lorke's, 1983). The animals in all groups were maintained on a commercial palletized diet daily and water was allowed ad libitum. The rat beddings were changed and replaced every day throughout the experimental period. Body weights of animals were monitored at three days intervals using a top loading Metler weighing balance. Fasting blood glucose was monitored at seven (7) days intervals with an on call plus blood glucometer.

\section{Collection of samples for analysis}

At the end of the $14^{\text {th }}$ day, the animals were fasted for 12 hours but had free access to water, then sacrificed. Whole blood was collected by cardiac puncture into sterile plain tubes. The blood was allowed to clot for 2 hours and thereafter centrifuged at 3000rpm for 10 minutes to obtained serum for biochemical assay.

\section{Biochemical assay}

Biochemical analyses were carried out using relevant biochemical kits (Agappes diagnostic laboratories limited, Switzerland).

\section{Statistical analysis}

The results obtained in this study were expressed as mean \pm SEM. Differences in mean values between groups were estimated by one-way ANOVA followed by Dunnet's post hoc test. The levels of significance was setup at $\mathrm{p}<0.05$.

\section{Results Effect of Extract on Enzyme activity}

In figure 1, a significant $(\mathrm{p}<0.05)$ decrease in ALT and ALP activity was observed in all experimental groups, while AST activity increased significantly $(\mathrm{p}<0.05)$ when compared to the diabetic control and Insulin treated groups, but similar to Normal control values. This suggest that the plant extract has hepatoprotective properties which compared well with results using standard insulin drug. 


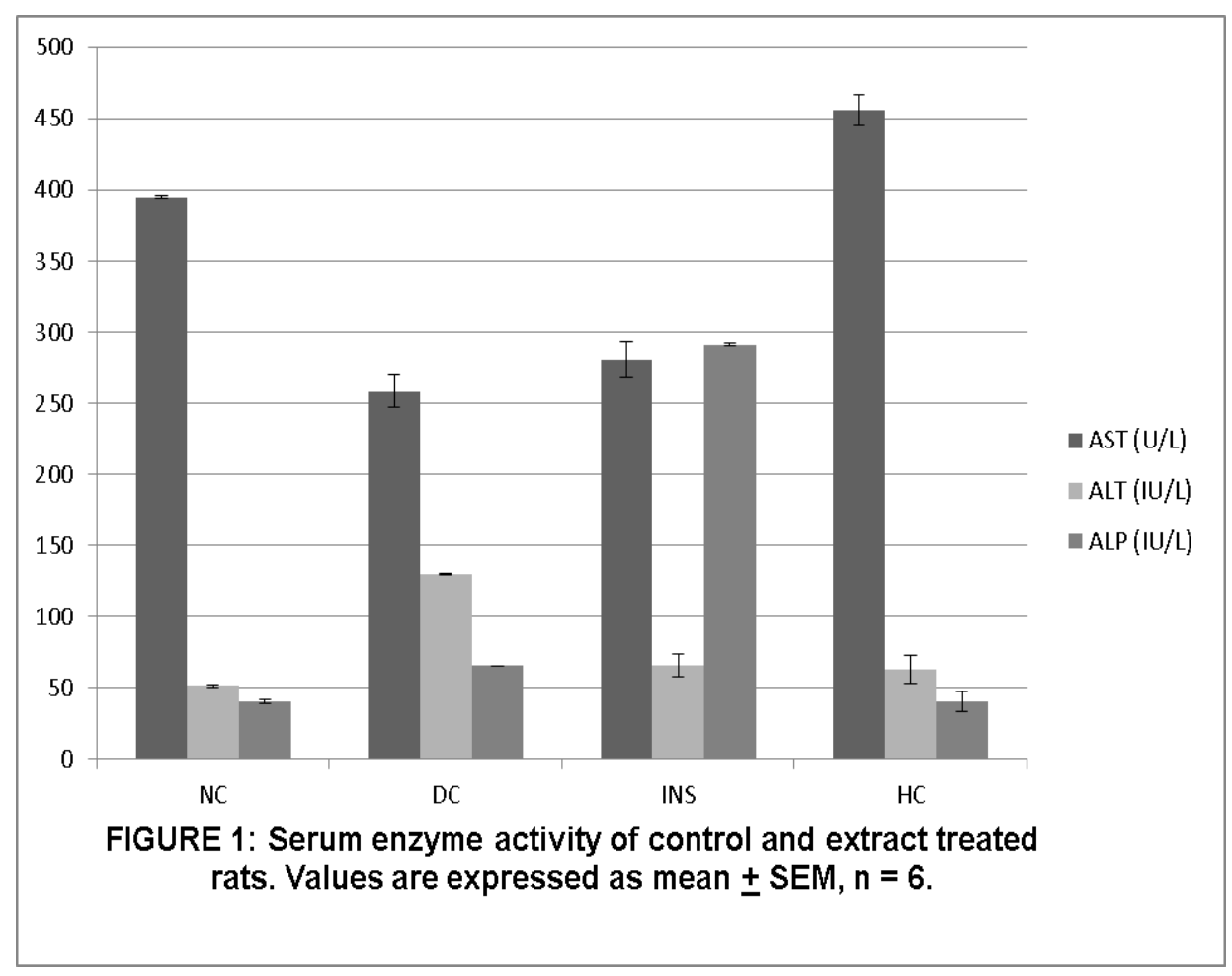

\section{Effect of Extract on Electrolyte balance}

Table 1 showed a significant $(\mathrm{p}<0.05)$ increase in $\mathrm{Na}^{+}$and Urea levels for both diabetic treated animals (groups $3 \& 4$ ) when compared to the diabetic control group. Also, the $\mathrm{K}^{+}$and $\mathrm{Cl}^{-}$concentrations showed significantly $(\mathrm{p}<0.05)$ high values in Heinsia crinite $(\mathrm{HC})$ treated group compared to diabetic control and insulin treated groups. These values showed close relation with the Normal control values. These results showed that the extract of Heinsia crinita is potentially nephroprotective, and confirms claims by ethno-medical practice of the use of this plant in the management of diabetes and its complications.

Table 1: Effect of extracts of Hencia crinita on Electrolyte balance of Experimental rat models.

\begin{tabular}{|c|c|c|c|}
\hline & $\begin{array}{l}\mathrm{K}^{+} \\
(\mathrm{Mmol} / \mathrm{l})\end{array}$ & $\begin{array}{l}\mathrm{Na}^{+} \\
(\mathrm{Mmol} / \mathrm{l})\end{array}$ & $\begin{array}{l}\text { Urea } \\
(\mathrm{Mg} / \mathrm{dl})\end{array}$ \\
\hline Normal control & $7.82 \pm 1.23$ & \multicolumn{2}{|l|}{$259.47 \pm 5.57 \quad 355.77 \pm 1.66 \quad 24.86 \pm 0.71$} \\
\hline Diabetic contro & $3.83 \pm 0.82 *$ & $127.09 \pm 14.43 *$ & \\
\hline Insulin & $3.19 \pm 0.28 *$ & $137.38 \pm 23.73^{\mathrm{a}} \quad 169.37 \pm 39.9^{\mathrm{b}}$ & \\
\hline Hencia crinita & $10.93 \pm 0.10^{\mathrm{a}}$ & $71.06 \pm 12.94^{\mathrm{a}}$ & $\begin{array}{l}78.48 \pm 3.75^{*} \\
\quad 66.04 \pm 6.06^{*}\end{array}$ \\
\hline \multicolumn{4}{|c|}{$\begin{array}{c}\text { Values are mean }+ \text { SEM, } \mathrm{n}=6 \\
* \text { Significantly different from normal control at } \mathrm{P}<0.05 \\
\mathrm{a}=\text { Significantly different from diabetic control at } \mathrm{P}<0.05\end{array}$} \\
\hline \multicolumn{4}{|c|}{$\begin{array}{l}\text { Effect of Extract on Fasting Blood Glucose } \\
\text { Table } 2 \text { shows the values of Fasting blood glucose (FBG) in all groups evaluated. A significant } \\
\text { reduction in fasting blood glucose was observed on the } 7^{\text {th }} \text { and } 14^{\text {th }} \text { day respectively in the insulin and HC } \\
\text { treated diabetic animals when compared with the basal fasting blood glucose in the normal control group. The } \\
\text { diabetic control animals showed high blood glucose levels throughout the } 14 \text { days of experimentation. The } \\
\text { extract of HC gave significant reductions in fasting blood glucose on the } 7^{\text {th }} \text { and } 14^{\text {th }} \text { day of FBG determinations } \\
\text { and compared well with the results obtained for standard insulin drug. }\end{array}$} \\
\hline
\end{tabular}


Hypoglycemic, Hepatoprotective and Nephroprotective Effects of...

Table 2: Changes in Fasting blood glucose following 14 days drug administration of extract on diabetic rat
Basal fasting blood
7th day
14th day
glucose

$\begin{array}{lc}\text { Normal control } & 97.50 \pm 2.44 \\ \text { Diabetic control } & 463.67 \pm 7.40 \\ \text { Insulin } & 437.50 \pm 90.16 \\ \text { Hencia crinita } & 440.00 \pm 2.12\end{array}$

$96.25 \pm 7.45$
$407.33 \pm 3.41 *$
$397.50 \pm 75.31 *$

$101.75 \pm 7.05$

$434.00 \pm 1.41^{*}$

$153.00 \pm 2.83 *$

$274.00 \pm 8.49 * c$

Values are Mean \pm SEM of three determinations.

Effect of Extract on body weight

Table 3 showed that there was no change in the body weight of diabetic animals treated with extracts of Heinsia crinita suggesting that the plant extract protected the animals from weight loss in diabetic conditions. On the other hand there was decrease in body weight of diabetic control animals on the $7^{\text {th }}$ day of experimentation, with a significant increase on the $14^{\text {th }}$ day due to recovery from alloxan effect. The control group gained weight as expected as a result of normal growth.

Table 3: Changes in body weight following 14 days administration of extract on diabetic rat

\begin{tabular}{|c|c|c|c|}
\hline & Basal body weight & 7th day & 14th day \\
\hline Normal control & \pm 8.35 & $96.26 \pm 7.94$ & $114.80 \pm 3.50$ \\
\hline Diabetic control & $148.37 \pm 6.82$ & $136.03 \pm 9.02 *$ & $172.42 \pm 5.83 *$ \\
\hline Insulin & $198.00 \pm 9.91$ & $\pm 11.78 *$ & $\pm 14.32 *$ \\
\hline Hencia crinita & $217.95 \pm 11.00$ & $207.65 \pm 4.14 *$ & $201.25 \pm 20.20 *$ \\
\hline
\end{tabular}

Values are mean \pm SEM, $\mathrm{n}=6$

*Significantly different from normal control at $\mathrm{P}<0.05$

\section{Effect of Extract on organ weight}

Table 4 showed the change in organ weight of kidney and liver at the end of 14 days of experimentation. The diabetic control group responded with significant $(\mathrm{p}<0.05)$ increase in kidney weight during the 14 days under diabetic condition when compared to the normal control and the insulin and HC treated groups respectively. The accumulation of fluid in the kidney during diabetes mellitus is common. The extract of $\mathrm{HC}$ effectively reduced the fluid content of the kidney in a manner similar to insulin, thus reducing the weight of the kidneys as observed in groups 3 and 4 in table 4 and tended to normal value. Liver weight significantly $(\mathrm{p}<0.05)$ decreased in diabetic control group compared to the normal control group. The liver became regenerated in groups 3 and 4 treated with insulin and extract of $\mathrm{HC}$ respectively. The liver weight significantly $(p<0.05)$ increased higher than the normal control group. The diabetic control untreated group liver weight did not regenerate and showed very low value (table 4). The regeneration of the kidney and liver weights supports the claims that extract of $\mathrm{HC}$ just like insulin is hepatoprotective and nephroprotective in diabetic states.

Table 4: Changes in organ weight following 14 days administration of Extract on diabetic rat

\begin{tabular}{lll}
\hline & Kidney Weight & Liver weight \\
\hline Normal control & $0.85 \pm 0.005$ & $3.68 \pm 0.17$ \\
DIabetic control & $8.07 \pm 0.80^{*}$ & $1.27 \pm 0.08^{*}$ \\
Insulin & $1.17 \pm 0.08^{\mathrm{a}}$ & $6.57 \pm 0.4^{* \mathrm{a}}$ \\
Hencia crinite & $1.50 \pm 0.00^{\mathrm{a}}$ & $7.95 \pm 1.10^{\mathrm{a}}$ \\
\hline
\end{tabular}

Values are mean \pm SEM, $n=6$

*Significantly different from normal control at $\mathrm{P}<0.05$

$\mathrm{a}=$ significantly different from diabetic control at $\mathrm{P}<0.05$ 
Hypoglycemic, Hepatoprotective and Nephroprotective Effects of...

\section{Disscusion}

In this study groups 2, 3 and 4 induced with diabetes using alloxan developed serum hyperglycemia. This condition was either due to pancreatic $\beta$-cells necrosis mediated by alloxan which enhances ATP dephosphorylation resulting in the generation of free radicals into the blood circulation or simply due to decrease in serum insulin or an integration of both processes. Diabetes induction and the generation of free radicals such as superoxide, hydrogen peroxide and hydroxyl radicals, caused the destruction of hepatic, pancreatic and kidney cells and tissues Gupta et. al 2011). The free radicals exerted pressure on the kidneys and affected the electrolyte balance of the organ causing nephrotoxicity and glomerular dysfunction (Efiong et. al. 2013). These free radicals also affected the liver cells causing hepatotoxicity which in turn affected the integrity of the cytochrome P450 monooxygenase enzyme system of the liver. This was shown by the large serum concentration of oxidative stress enzymes including AST, ALT and ALP. The treatment of diabetic groups 3 and 4 with standard insulin and HC extract reversed the diabetic conditions and protected the animals against hepatotoxicities and nephrotoxicities (Gupta et. al. 2011; Efiong et. al 2013).

It was concluded that the antidiabetic effect observed may be due to the bioactive secondary compounds in HC extract which caused increased insulin release through either antioxidant activity or the regeneration of $\beta$-cells of the islets of Langerhans (Gupta et. al 2011).

The results from this study have indicated that Heinsia crinita do actually possess hypoglycemic properties. These properties may be due to the presence of bioactive secondary compounds that have been confirmed to be present in the plant, and these include polyphenols, saponins, flavonoids and alkaloids among others. This study corroborates previous studies by Igile et. al (1995); Atangwho et. al (2009), Mgbeje et. al (2013), Edet et. al (2013) and Efiong et. al. (2013) that plant extracts containing polyphenols, flavonoids, saponins and other secondary compounds of plant metabolism actually possess hypoglycemic, hepatoprotective and nephroprotective activities. Thus confirming claims by ethno-pharmacological practitioners of the use of herbs and plant materials for medical purposes.

In diabetic patients, altered enzymatic activities of AST, ALT and ALP are physiologically and clinically important. These enzymes are located in the cytosol or mitochondria of a variety of tissues both in the liver and other organs. Any perturbations to these cells or tissues as a result of the presence of a xenobiotic substance or free radical may affect the overall biochemical processes in experimental animals and may result in increase or decrease in the activity of such enzymes (Edet et al., 2011).

The increased levels of transaminases, which are active in the absence of insulin because of increased availability of amino acids in diabetes, may be responsible for the increased glucogenesis and ketogenesis observed in diabetes. The fact that ALT occurs in higher concentration in the liver than elsewhere, it implies that increased serum ALT activity specifically reflects hepatic damage, which occurs normally in diabetes. The present study showed a decrease in ALT and ALP activity in all experimental animals with AST activity showing a significant $(\mathrm{p}<0.05)$ increase compared with the diabetic control and Insulin treated groups, but showed a close relationship to the normal control group. The decrease in ALT and ALP activity may be due to the presence of antioxidative principles such as flavonoids, polyphenols and saponins in the extract of Heinsia crinite (HC), which have been reported to be hepatoprotective (Mgbeje et. al 2013; Edet et. al. 2013).

Diabetes mellitus results in an increase in the plasma glucose leading to cell dehydration and migration of $\mathrm{K}^{+}$into the extracellular fluid of kidney cells. This leads to increase in the activity of parietal cells of the distal and cortical collecting tubules of the kidneys, resulting in increased renal $\mathrm{K}^{+}$excretion (Kang et al., 2005). It is therefore possible that the increased electrolyte and water levels usually observed in diabetes could lead to depletion of the extracellular fluid electrolyte and thus lead to the excretion of electrolyte by parietal and non-parietal cells (Onunogbo et al., 2012). This may therefore account for the significant reduction in the $\mathrm{Na}^{+}$and $\mathrm{K}^{+}$concentrations of the rat kidney compared to the control. This study showed that no significant changes in renal markers in the serum were observed, and this is confirms the safety of the plant extract (HC) on the kidney. Diabetic nephropathy is a microvascular complication of diabetes (Kang et al., 2005).

Studies have shown an association between hyperglycemia and decreased body weight of diabetic models including man (Igile et. al., 1995; Atangwho et. al. 2009 \& 2010). Tissue wasting is characteristic of poor glycemic control in diabetes mellitus and this usually enhances protein and fat mobilization resulting in eventual weight loss (Cotran et al., 1999; Atangwho et al., 2007a). In this study, there was a significant $(\mathrm{p}<0.05)$ difference in decrease in body weight between diabetic treated rats and the diabetic control animals on the $7^{\text {th }}$ day of the experimental period. The difference was even more pronounced and significant on the $14^{\text {th }}$ day of the experimental period compared to the normal control group

Diabetes causes lipid peroxidation-mediated tissue damage to the pancreas, liver, kidney, and heart. This damage may be related directly to changes in the metabolic processes in which these enzymes are involved. The increase in the serum levels of these enzymes in diabetic rats may be due to leakage and migration of these enzymes from hepatic tissues and other key organs into the blood stream (Prince and Menon, 2000). A key morphological change associated with sustained hyperglycemia in diabetic state is the accumulation of glycogen granules in the distal tubules, which leads to renal hypertrophy (Kang et al., 2005).

In the present study, a significant $(\mathrm{p}<0.05)$ increase in kidney weight of diabetic control group was observed when compared to the normal control. Upon treatment with extract and insulin (Groups 4 \& 3) respectively, a significant decrease in kidney weight was observed and compared well with the normal control group. There was a reduction in liver weight of the diabetic control group when compared to the normal control group. On treatment with extract and insulin (Groups 4 \& 3) respectively, a significant increase in liver weight was observed which compared with the normal control group. 


\section{Conclusion}

This study showed that the methanolic extract of Heinsia crinita $(\mathrm{HC})$ is a potential antidiabetic agent and could protect the body against liver and kidney toxicities related to diabetes and its complications. Thus confirming its general use in ethno-medical practice to cure and manage diabetes, ulcers, cough, malaria and stomach pains. There is a need for further phytochemical investigation to isolate, characterize and identify the active compounds in this plant material which is used both as a herb and a green-leafy vegetable, and to evaluate such pure compounds for biochemical activity in order to confirm which compounds are responsible for anti-diabetic and anti-oxidative functions.

\section{Disclosure}

The authors hereby disclose that there are no conflicts of interest, with respect to this work.

\section{REFERENCE}

[1.] Lorke, D. (1983). A new approach to practical acute toxicity testing. Archives of toxicology, 53:275-287.

[2.] Prince P S M, and Menon V.P (2000). Hypoglycaemic and other related actions of tinospora cardifolia roots in alloxan - induced diabetic rats. J. Ethnopharmacol. 70: 9-15.

[3.] Kang J, Dai X S, Yu T B, Wen B, and Yang Z W, (2005). Glycogen accumulation in renal tubules, a key morphological change in the diabetic rat kidney. Acta. Diabetol, 42: 110-116.

[4.] Enyi-idoh K H, Ikpeme E M, Iwuh G. C (2012). Antibacterial activity of gnetum africanum and heinsia crinita on diarrhoeagenic bacteria stool isolates from children in Calabar south Lga, cross river state, Nigeria. Transnational journal of science and technology march 2013 edition vol.3, no.3

[5.] Edet, E.E; I.J. Atangwho, M.I. Akpanabiatu, T. E. Edet, F.E. Uboh, E, David-Oku (2011). Effect of gongronema latifolium leaf extract on some liver enzymes and protein levels in diabetic and non diabetic rats. J. Pharm. Biomed. Sci., 1(5) 104-107.

[6.] Abo, k. A., Adeyemi, A. A. And Adeite, D. A (2000). Ethnobotanical survey of plants used

[7.] In the treatment of infertility and sexually transmitted diseases in south-west nigeria. African journal of medical sciences $29,325-$ 327.

[8.] Ajibesin, K., Ekpo, B. A., Bala, D. N., Essien, E. E. And Adesanya, S. A. (2008). Ethnobotanical survey of akwa ibom state of nigeria. J. Ethnopharmacol 115, 387-408.

[9.] Mahesh, B. And Satish, S. (2008). Antimicrobial activity of some important medicinal

[10.] Plant against plant and human pathogens. World j. Agric. Sci. 4(s), 839-843.

[11.] Cotran, R. S., kumar, V. \& Collins, T. (1999). Robbins pathologic basis of disease (6 $6^{\text {th }}$ ed.). Philadelphia: W. B. Saunders Coy.

[12.] Atangwho, I. J., Ebong, P. E., Eyong, E. U., Eteng, M. U. \& Uboh, F. E. (2007a). Vernonia amygdalina del.: a potential prophylactic antidiabetic agent in lipids complication. Global journal of pure and applied sciences, 13 (1): 103-106

[13.] Igile, G. O., Oleszek, W., Jurzysta, M., Burda, S., Fafunso, M. \& Fasanmade, A. A. (1995). Nutritional assesment of vernonia amygdalina leaves in growing mice. Journal of agriculture and food chemistry, 43: 2162-2166.

[14.] Grace. E. Effiong., Justin I Atangwho, Godwin I. Igile, Bob I A. Mgbeje, Eyong E. Eyong and Patrick E. Ebong (2013): antioxidant enzymes activity and hormonal changes following administration of ethanolic leaves extracts of nauclea latifolia and gongronema latifolium in streptotozocin induced-diabetic rats. European journal of medicinal plants. 3(2): 297-309.

[15.] Item Justin Atangwho, Patrick E. Ebong, Eyong U. Eyong (2010). Combined extracts of Vernonia amygdalina and Azadirachta indica may substitute insulin requirement in the management of type 1 diabetes. Research journal of medicines and medical sciences, 5(1):35-39.

[16.] Item Justin Atangwho, Patrick E. Ebong, Godwin E. Egbung and Ime F. Ani (2009). Effects of co-administration of extracts of Vernonia amygdalina and Azadirachta indica on serum electrolyte profile of diabetic and non diabetic rats. Australian journal of basic and applied sciences, 3 (3): $2974-2978$.

[17.] C. C Onunogbo, O. C. Ohaeri and C. O. Eleazu(2012). Effect of mistletoe (Vascium album) extract on the blood glucose, liver enzyme and electrolyte balance in alloxan induced diabetic rats. Am. J. Biochem. Mol. Biol. Issn 2150-4210.

[18.] Edet. EE, Edet TE, Akpanabiatu MI, David-Oku E, Atangwho IJ, Igile GO, Mgbeje BIA and Uboh FE(2013).Toxicopathological changes and phytochemically-induced alleviation in Diabetic Rats Treated with Gongronema latifolum Leaf Extracts. J. Medicine and Medical Sciences, Vol. 4, No. 5, pp. 204-213

[19.] Mgbeje, B.I.A., Essien, A.N., Iwara, I.A., Egbung, G.E, Igile, G.O., Ebong, P.E (2013). Lipid profile and hepatoprotective effects of combined leaf extracts of Azadirachta indica (Neem) and Peristrophe bicalyculata in Alloxan-induced diabetic rats. International Journal of Phytomedicine, Vol 5, No. 2

[20.] Efiong, E. E., Igile, G. O., Mgbeje, B.I.A., Out, E.A., Ebong, P.E (2013). Hepatoprotective and anti-diabetic effect of combined extracts of Moringa oleifera and Vernonia amygdalina in streptozotocin-induced diabetic albino Wistar rats. Journal of Diabetes and Endocrinology, Vol 4, No. 4, pp. 45-50

[21.] Gupta, R; Sharma, A.K; Dobhal, M.Pl Sharma, M.C, Gupta, R.S (2013). Antidiabetic and antioxidant potential of $\beta$-sitosterol in streptozotocin-induced experimental hyperglycemia. J. Diabetes 3, 29-37

[22.] Maton A, Jean H, McLaughlin CW, Warner MQ, Lattart D, Wright JD (1993). Human Biology and Health. Eaglewood Cliffs, New Jersey, Prentice Hall, USA

[23.] Wild S, Roglic G, Green A, Sicree A, King H (2004). "Global prevalence of diabetes: Estimates for the year 2000 and projections for 2030”. Diabetes Care 27(5):1047-1053. 